\title{
The relevance of non-formal Biology Olympiad training for upper secondary school students
}

\author{
Justus Mutanen and Maija Aksela \\ LumA Science Education Centre, University of Helsinki, Finland
}

\begin{abstract}
Science competitions, such as the International Biology Olympiad, arenonformal education targeted to upper secondary school students with high abilities. However, there is little knowledge about what is the relevance of training for a science competition. In this study, Finnish Biology Olympiad training participants were researched in the context of relevance of science education. In total, 28 students filled in questionnaires and participated in interviews. It was found out that the students experienced the training to be especially individually relevant for them, and there was no significant difference between genders. Based on the results, vocational and societal topics should be taken into more account in designing Olympiad trainings.
\end{abstract}

Keywords: high ability students, non-formal education, relevance, science education, science competitions, out-of-school learning

Contact: justus.mutanen@helsinki.fi

DOI: https:/ / doi.org/ 10.31129/ LUMAT.6.2.311

\section{Introduction}

The decline of interest and engagement in science as well as growing need of skilled scientists have aroused concern in many Western countries (Osborne, Simon, \& Collins, 2003; Vihma \& Aksela, 2014). Non-formal, out-of-school education might help to engage young students to math and science (STEM) careers (Tolppanen, Vartiainen, Ikävalko, \& Aksela, 2015; Vihma \& Aksela, 2014) and understand scientific inquiry (Antink-Meyer, Bartos, Lederman, \& Lederman, 2016). The development of non-formal education is also promoted by the European Union (European Union, 2015).

Most science competitions pursue to promote interest in science and scientific careers, but it is still unknown whether those objectives can be fulfilled. According to earlier research, science competitions have been identified to help the students realize their talent (Campbell, Wagner, \& Walberg, 2000). In addition, competitions can reinforce career choices and interest in science, but personal topics of interests, teachers and parents also have a big effect on future vocational choices (Krapp \& Prenzel, 2011; Sahin, Gulacar, \& Stuessy, 2015). According to Campbell et al. (2000), 
it is assumed that competitions are important because the schools rarely have differentiated curriculums for advanced students. It is also assumed that students with high abilities are attracted to taking part in competitions and they are motivated by these activities (Campbell et al., 2000). These assumptions have not been confirmed, as science competitions have received little scientific interest (Abernathy \& Vineyard, 2001). Most studies about science competitions have been conducted in Western countries, and various cultural factors have been neglected (Lim, Cheah, \& Hor, 2014). Especially, the long-term effects of the science competitions are poorly known. Because of the lack of educational research on this field, defining the aims, purposes and objectives of the competitions can be challenging.

The participants of science Olympiad and other science competitions have been researched in a few studies. It has been shown that the participants of these events are likely to choose a scientific career and succeed in academic life (Campbell et al., 2000). Family support and not fearing failure are important predictors of students' success (Urhahne, Ho, Parchmann, \&Nick, 2012), as well as parents' educational level (Tirri, 2000). Participants also consider that both ability and effort are needed to succeed in competitions (Tirri \&Nokelainen, 2010).

Science Olympiad training has been researched by Oliver and Venville (2011), who found that the students participating in science Olympiad training had a higher attitude towards science compared to other students of this age. It was also discovered that the students experienced science to be an easy school subject and didn't pursue to learn it. To support those students, there should be more challenges in science as well as academic support in science learning process. (Oliver \& Venville, 2011) Biological competitions might also be a meaningful tool to improve young students' interest in science and enabling to maintain and stabilize it (Staziński, 1988). However, it is yet to be defined what kind of effects these competitions and training courses have on interest or motivation or how the students value the competitions and training.

The International Biology Olympiad (IBO) is a yearly competition for secondary school students interested in biology. During the competition, both practical skills and theoretical knowledge are tested. The objectives of the IBO competition are to 1) stimulate active interest in biological studies, 2) promote networking and understanding between biology students, and 3) promote and exchange ideas about biology education' (IBO Coordinating Centre, 2015). 
Most countries taking part in the IBO competition also arrange a national Biology Olympiad or competition and a training course for the students. In Finland, students can participate in the National Biology Competition. Based on the competition, approximately ten students with the highest scores are selected for the IBO training, consisting of an online training course and two training weeks at university. To help the students orient towards the training, the Campbell's Biology textbook is sent to the students, and the students receive online training questions to help learning the material. Training weeks consist of laboratory experiments, designing and executing a small research project, as well as research laboratory visits and a final exam. In the end of the training, four students are selected for the IBO team to represent their country in the IBO competition, based on their score on the final exam.

\section{The Relevance of Science Education}

Science education is often experienced to beirrelevant for the students (Dillon, 2009), and hence students may not become interested in scientific topics. To make students develop positive attitudes towards science, science education should be relevant for students in the individual level. In addition, it is important that science education is relevant for the society and the future vocational life of the students. (Cleaves, 2005; Hofstein, Eilks, \& Bybee, 2011; Osborne et al., 2003) Advanced students consider science to be relevant for them individually, but also for society and their future vocation (Vesterinen, Tolppanen, \&Aksela, 2016), which should be taken into account when designing education for students with high abilities.

The relevance of science competitions hasn't been researched, even though various science competitions are organized every year. Relevance is widely used concept in educational policies and research, but there has been ambiguity in the definition (Newton, 1988; Stuckey, Hofstein, Mamlok-Naaman, \& Eilks, 2013). There are various examples of studies where 'relevant' is interpreted synonymous for 'interesting', 'motivating', 'needful' or 'meaningful' (Holbrook, 2008; Levitt, 2001; Simon \& Amos, 2011; Sjøberg \& Schreiner, 2010). Sometimes real-life effects on students or society are used to assess the relevance of education (Hofstein \& Kesner, 2006). Stuckey et al. (2013) argue that there are differences in relevance and interest as science education can be relevant for the students even though it wouldn't be interesting to them. Interestingness is not the only criterion for relevant science 
education, but educators should also consider including vocational and societal aspects of relevance in their teaching.

The relevance of science education is also discussed by Roberts (2007), who presents two visions for scientific literacy: On the one hand, science education is relevant in developing scientific thinking skills and fostering growth of future scientists (Vision I); on the other hand, it's also relevant in everyday life and society (Vision II). (Roberts, 2007; Roberts \& Bybee, 2014) The definition of the relevance of science education also depends on who decides what is relevant. Academic scholars have traditionally defined what is relevant in science education. However, ordinary people also face science-related problems in their everyday life; employers emphasize working-life skills in science education; the media makes people become interested in scientific topics; experts who are concerned with general public have also interest in science education; and students themselves may be interested in scientific topics as well. (Aikenhead, 2006, p. 32) In conclusion, the relevance of science education is a multifaceted issue debated by multiple interest groups with conflicting views.

Based on literature on the relevance of science education, Stuckey et al. (2013) have synthesized a theoretical framework, in which relevance is defined to have a 1) temporal component, 2) an intrinsic-extrinsic component and 3) three different dimensions of individual, societal and vocational relevance (Figure 1). They also have pointed out that relevant science education should have positive effects on a life of a student, but this effect can be related to the individual interests of a student or to the societal or vocational needs. All three dimensions, individual, vocational and societal relevance, should be present to achieve the goals of science education.

Figure 1. The components and dimensions of relevant science education, according to Stuckey et al. (2013).

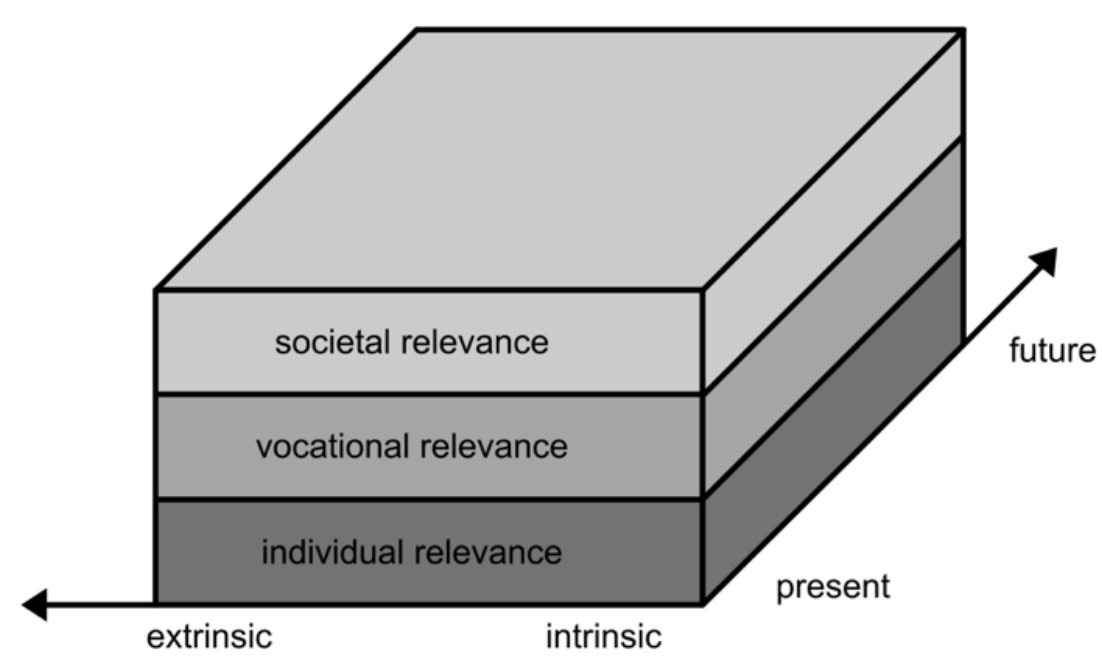


Science Olympiad training can be classified as non-formal education (Eshach, 2007) because it has some features of both formal education (e.g. a curriculum and learning objectives) and informal education (e.g. voluntariness). The requirement of relevant science education does not apply only to formal education, but also to non-formal and informal education. The relevance of non-formal science education has gained little scientific interest, but e.g. Tolppanen et al. (2015) have analysed the relevance of nonformal STEM education in Finland, and found that non-formal, out-of-school science education can be relevant for the students individually, vocationally and societally, and relevance should be taken into account when designing science education for high ability students.

In this study, the participants of Finnish Biology Olympiad training courses were researched to examine the relevance of the training. In addition, participants' views on the relevance of biology education were researched to get more knowledge of the relevance of the training. Secondly, students' aims and expectations and their learning experiences were explored to get more knowledge to develop more relevant training for the participants. The research questions were:

1. How is Biology Olympiad training relevant for the participants?

2. How is it possible to make Biology Olympiad training relevant for the participants?

\section{Materials and Methods}

In the first part of this research, the relevance of the training was examined by analysing the experiences of the previous participants. In 2014, an online questionnaire was sent to the previous participants from years 2008-2014 (65 participants in total). 35 previous participants (54\%) answered the questionnaire: 49 $\%$ of the respondents were male and $51 \%$ female, and $49 \%$ were selected for the IBO team. $83 \%$ of the respondents were studying in the university (Bachelor's or Master's level), $6 \%$ were $\mathrm{PhD}$ students and $11 \%$ were in other position. $31 \%$ of the respondents had chosen biosciences, $40 \%$ medicine, and $29 \%$ other disciplines.

The questionnaire contained background information fields (gender, year of participation, and current discipline of studies or vocation) and 15 statements about the relevance of the training (see Table 1). For each statement, the participants had to 
choose a value from a five-point Likert scale ranging from 'do not agree at all' to 'strongly agree'. To assess the reliability of each dimension, Cronbach's alpha was calculated for each dimension.

Table 1. The questions in questionnaire sent to the previous Finnish Biology Olympiad training participants.

\begin{tabular}{|c|c|c|}
\hline Number & Statement & $\begin{array}{l}\text { Dimension of } \\
\text { relevance }\end{array}$ \\
\hline 1 & The experiences I got during the training have been memorable. & Individual \\
\hline 2 & $\begin{array}{l}\text { The knowledge and skills, that I learned during the training, helped me } \\
\text { to choose my future studying place. }\end{array}$ & Vocational \\
\hline 3 & $\begin{array}{l}\text { The knowledge and skills, that I learned during the training, have been } \\
\text { useful in my everyday life. }\end{array}$ & Individual \\
\hline 4 & The training helped me to develop my social skills. & Societal \\
\hline 5 & I learned knowledge and skills that are useful in vocational life. & Vocational \\
\hline 6 & The training made me better in solving problems. & Individual \\
\hline 7 & $\begin{array}{l}\text { The training helped me to understand, what's the meaning of science to } \\
\text { the society. }\end{array}$ & Societal \\
\hline 8 & $\begin{array}{l}\text { The training helped me to get connected to other people who think like } \\
\text { me. }\end{array}$ & Vocational \\
\hline 9 & $\begin{array}{l}\text { The training helped me to understand societal issues connected to } \\
\text { science. }\end{array}$ & Societal \\
\hline 10 & $\begin{array}{l}\text { The knowledge and skills, that I learned during the training, have been } \\
\text { helpful in my studies. }\end{array}$ & Individual \\
\hline 11 & The training was interesting. & Individual \\
\hline 12 & The training affected or strengthened my career choice. & Vocational \\
\hline 13 & The training helped me to understand science better. & Individual \\
\hline 14 & The training gave me a good insight into jobs in science. & Vocational \\
\hline 15 & I learned to work with different people during the course. & Societal \\
\hline
\end{tabular}

Based on the results, a sum score was calculated for each dimension. The sum scores of each dimension and the year of participation were compared by calculating the Spearman correlation coefficient (see Table 5). The effects of background factors were examined by conducting Mann-Whitney U-tests.

To examine the effects of the training, a qualitative study was carried out, the subject being the Finnish IBO training during 2014 and 2015. During this period, two student groups took part in the training: the first group was trained for the IBO competition organized in 2015, and the second group was trained for IBO 2016. An online questionnaire containing open-ended questions was sent to the students before and after the two training weeks. In addition, the students were interviewed after the 
training weeks (semi-structured interviews). In total, 28 students filled in the questionnaires and participated in the interviews.

Before the training week the students were asked why they are interested in biology and what kind of aims and expectations they have for the course. After the training week, the students were asked what kind of topics they learned during the week.

A qualitative content analysis approach was applied to analyse the qualitative data and both inductive and deductive approaches were used: In inductive content analysis, the content is reduced to different themes based on the data, whereas a theoretical framework sets the direction for the analysis in deductive content analysis (Elo \& Kyngas, 2008). First, the questionnaires and interviews were analysed, and different themes were created based on the data. Secondly, the previously formed themes were classified in bigger groups based on deductive content analysis. In this case, the theory of relevance of science education (Stuckey et al., 2013) was applied as the basis of deductive analysis phase.

Thus, the whole process included both inductive and deductive phases:

- The inductive phase

1. Reading through the data and identifying the relevant excerpts.

2. Forming the initial groups based on the data.

3. Classifying the excerpts in the initials groups.

4. Checking the initial groups and refining them. Forming new groups, if necessary. Reclassifying the excerpts if necessary.

5. Classifying groups in bigger themes, if applicable.

6. Re-reading and re-discussion of the data.

- The deductive phase

1. Classifying the themes in the theoretical framework.

2. Checking the themes, groups and original excerpts and checking their applicability in the theoretical framework.

3. Re-forming the inductive phase classification, if necessary.

When analysing the reasons to be interested in biology, after the inductive analysis process, the data were classified in nine themes. In the deductive content analysis phase, the previously formed themes were classified to belong to individual, 
vocational or societal relevance, based on the description by Stuckey et al. (2013). The classification of the data is presented in Table 2. The excerpts are translated from Finnish into English.

Table 2. The classification of students' reasons to be interested in biology.

\begin{tabular}{lll}
\hline $\begin{array}{l}\text { Dimension of } \\
\text { relevance }\end{array}$ & Theme & An example \\
\hline $\begin{array}{l}\text { Individual } \\
\text { relevance }\end{array}$ & Understanding the nature & $\begin{array}{l}\text { 'biology helps you to understand the World } \\
\text { around you, and environment' }\end{array}$ \\
& $\begin{array}{l}\text { Practical applications of biology } \\
\text { Consistency of biology }\end{array}$ & $\begin{array}{l}\text { 'practical applications [of biology] are useful' } \\
\text { '[biology-related topics] are more logical and can } \\
\text { be deduced rather than memorized' }\end{array}$ \\
& Understanding oneself & $\begin{array}{l}\text { 'you can understand the functions of your own } \\
\text { body.' }\end{array}$ \\
& Hobbies and free time activities & 'knowing species is important as a hobby' \\
\hline $\begin{array}{l}\text { Societal } \\
\text { relevance }\end{array}$ & $\begin{array}{l}\text { All-round education / general, } \\
\text { layperson knowledge } \\
\text { Topicality of biology }\end{array}$ & 'knowing biology is a part of all-round education' \\
& Caring about environment and & 'biology can be used to explain many important \\
& nurrent topics' & 'I want to take care of environment and nature' \\
\hline $\begin{array}{l}\text { Vocational } \\
\text { relevance }\end{array}$ & Future studies / vocation & 'They are likely to be related to my future studies' \\
\hline
\end{tabular}

Using the previously described content analysis process, the aims and expectations of the students were analysed. The aims and expectations were classified in 15 themes in the inductive phase of the process, and these themes were classified as individual, vocational or societal relevance in the deductive phase. The classification is presented in Table 3. The excerpts are translated from Finnish. 
Table 3. The classification of students' aims and expectations for the training.

\begin{tabular}{|c|c|c|}
\hline $\begin{array}{l}\text { Dimension of } \\
\text { relevance }\end{array}$ & Theme & An example \\
\hline \multirow{9}{*}{$\begin{array}{l}\text { Individual } \\
\text { relevance }\end{array}$} & Getting to know new people & 'I want to--get to know new people' \\
\hline & Learning practical skills & 'learning to use new devices' \\
\hline & Getting new experiences & 'to learn and have a novel experience' \\
\hline & Learning to apply knowledge & $\begin{array}{l}\text { 'different methods, and testing - how can } \\
\text { you apply it in practise' }\end{array}$ \\
\hline & $\begin{array}{l}\text { Deepening knowledge in a special } \\
\text { topic of interest }\end{array}$ & 'learning microbiology in detail' \\
\hline & Research-related topics & '[to learn] about modern research topics' \\
\hline & Performing well & 'managing to do my research' \\
\hline & Reviewing one's knowledge & 'Recalling what I've learned before' \\
\hline & Getting to the IBO team & 'to get to the [IBO] competition' \\
\hline \multirow[t]{4}{*}{$\begin{array}{l}\text { Vocational } \\
\text { relevance }\end{array}$} & Matriculation exams & $\begin{array}{l}\text { 'learning things preparing for the } \\
\text { matriculation exams' }\end{array}$ \\
\hline & Future studies & $\begin{array}{l}\text { 'Broaden the views - - what's learning a } \\
\text { subject in the university' }\end{array}$ \\
\hline & $\begin{array}{l}\text { Getting to know companies / } \\
\text { industry }\end{array}$ & $\begin{array}{l}\text { 'Visiting the companies - - would be } \\
\text { interesting' }\end{array}$ \\
\hline & Getting a course for the studies & $\begin{array}{l}\text { 'Having a course [for the upper secondary } \\
\text { school]' }\end{array}$ \\
\hline Societal relevance & A good working environment & '[how to] work without pressure' \\
\hline
\end{tabular}

Similarly, the learning experiences from post-training questionnaires and interviews were analysed. During the inductive phase, the learning experiences were classified in 11 groups, and these groups were further reduced into 6 themes. In the deductive phase, the 6 themes were classified to represent either individual, vocational or societal relevance. The classification is presented in Table 4. The excerpts are translated from Finnish. 
Table 4. The classification of students' learning experiences.

\begin{tabular}{|c|c|c|c|}
\hline $\begin{array}{l}\text { Dimension of } \\
\text { relevance }\end{array}$ & Theme & Group & An example \\
\hline \multirow[t]{7}{*}{$\begin{array}{l}\text { Individual } \\
\text { relevance }\end{array}$} & $\begin{array}{l}\text { Learning } \\
\text { practical work }\end{array}$ & $\begin{array}{l}\text { How devices work / } \\
\text { using devices }\end{array}$ & 'a little bit-- how devices work' \\
\hline & & $\begin{array}{l}\text { Learning practical } \\
\text { methods }\end{array}$ & 'having the courage to do practical work' \\
\hline & $\begin{array}{l}\text { Learning } \\
\text { theoretical } \\
\text { knowledge }\end{array}$ & $\begin{array}{l}\text { Theoretical } \\
\text { knowledge about a } \\
\text { biological topic }\end{array}$ & $\begin{array}{l}\text { 'I learned most about microbiology, but also } \\
\text { plant physiology was really a new topic' }\end{array}$ \\
\hline & & $\begin{array}{l}\text { Connecting theory } \\
\text { with practise }\end{array}$ & $\begin{array}{l}\text { 'learning new ways of thinking, from a } \\
\text { theoretical perspective, such as how the size } \\
\text { of a molecule affects it filtration [in } \\
\text { biochemistry]' }\end{array}$ \\
\hline & $\begin{array}{l}\text { Learning about } \\
\text { research }\end{array}$ & Research funding & $\begin{array}{l}\text { '[understanding the] price of everything, } \\
\text { such as an electron microscope--could be } \\
\text { worth of millions' }\end{array}$ \\
\hline & & What's research like & $\begin{array}{l}\text { 'You can do whatever you like if you find-- } \\
\text { your own project' }\end{array}$ \\
\hline & & $\begin{array}{l}\text { How to apply scientific } \\
\text { knowledge }\end{array}$ & $\begin{array}{l}\text { 'the importance of PCR in all medical } \\
\text { research et cetera' }\end{array}$ \\
\hline \multirow[t]{3}{*}{$\begin{array}{l}\text { Vocational } \\
\text { relevance }\end{array}$} & $\begin{array}{l}\text { Getting help to } \\
\text { succeed at } \\
\text { studies }\end{array}$ & $\begin{array}{l}\text { Succeeding in the } \\
\text { matriculation exams }\end{array}$ & $\begin{array}{l}\text { 'the matriculation exam could have a special } \\
\text { question about this kind of practical work' }\end{array}$ \\
\hline & $\begin{array}{l}\text { Science as a } \\
\text { vocation }\end{array}$ & $\begin{array}{l}\text { Understanding the } \\
\text { nature of a scientific } \\
\text { career }\end{array}$ & $\begin{array}{l}\text { 'wherever you end up - - as a career }-- \text { you } \\
\text { get to know what's going on in this field of } \\
\text { research' }\end{array}$ \\
\hline & & $\begin{array}{l}\text { Learning skills needed } \\
\text { in vocational life }\end{array}$ & $\begin{array}{l}\text { 'things that you might need -- in your } \\
\text { vocation' }\end{array}$ \\
\hline $\begin{array}{l}\text { Societal } \\
\text { relevance }\end{array}$ & $\begin{array}{l}\text { Science and } \\
\text { society }\end{array}$ & $\begin{array}{l}\text { The importance of } \\
\text { science for the society }\end{array}$ & 'the meaning - - of biology to the society' \\
\hline
\end{tabular}

In the classification process, all the answers given by a single student were combined, and based on the classification, it was marked down whether the student had mentioned a specific theme in their interviews or questionnaires. Finally, the results of the three training weeks were combined, and the percentage of students who mentioned the theme was calculated.

The number of participants of this study is relatively small, as it was selected to focus on the Finnish Biology Olympiad training. As there are only about 10 students participating in this course every year, it is challenging to involve large groups for this kind of study. To address this issue, different levels of triangulation were applied: 1) 
time triangulation, 2) investigator triangulation and 3) methodological triangulation. First, data were collected from previous Olympiad training participants, and also from three different training weeks after the refinement of the training. Second, to improve the reliability and validity of results, a second researcher used the described classification to classify the data. The inter-rater agreement was assessed by calculating Cohen's kappa value (J. Cohen, 1960). Third, both quantitative and qualitative approaches and different kinds of data collection methods were used to get more reliable data about the phenomenon (L. Cohen, Manion, \& Morrison, 2013, p. 196).

\section{$4 \quad$ Results}

In the quantitative part of this study, the three dimensions of relevance (individual, vocational and societal) of the Biology Olympiad training were measured by using a questionnaire developed in this study. The reliability index of Cronbach's alpha was 0.75 for individual relevance (statements $1,3,6,11$ and 13), 0.79 for vocational relevance (statements $2,5,10,12$ and 13) and 0.84 for societal relevance (statements $4,7,8,9$, and 15). The participants gave higher absolute values to the individual relevance dimension compared to the other two dimensions, which can also be seen in Figure 2. There was moderate correlation between different dimensions of relevance, but little correlation between the year of participation and experienced dimensions of relevance (Table 5).

Table 5. Spearman correlations between the dimensions of relevance experienced by the participants of Finnish Biology Olympiad training, and their year of participation.

\begin{tabular}{llll}
\hline & Individual relevance & Societal relevance & Vocational relevance \\
\hline Societal relevance & $0.535\left(p=0.001^{* *}\right)$ & & \\
Vocational relevance & $0.668\left(p<0.001^{* *}\right)$ & $0.495\left(p=0.003^{* *}\right)$ & \\
Year of participation & $0.239(p=0.166)$ & $0.335\left(p=0.049^{*}\right)$ & $0.310(p=0.070)$ \\
${ }^{*} p<0.05 .{ }^{* *} p<0.01$ & & & \\
\hline
\end{tabular}

According to Mann-Whitney U-tests, there were no significant differences between genders and their experiences of individual, vocational and societal relevance ( $p=0.610, p=0.193$ and $p=0.454$, respectively). If a student had been selected for the IBO team, they experienced that the training was more relevant for them both 
individually, vocationally and societally $(p=0.002, p=0.045$ and $p=0.014$, respectively). The means of sum variables for these groups are displayed in Figure 2.

The dimensions of relevance in Finnish IBO training according to participants $(\mathrm{N}=35)$

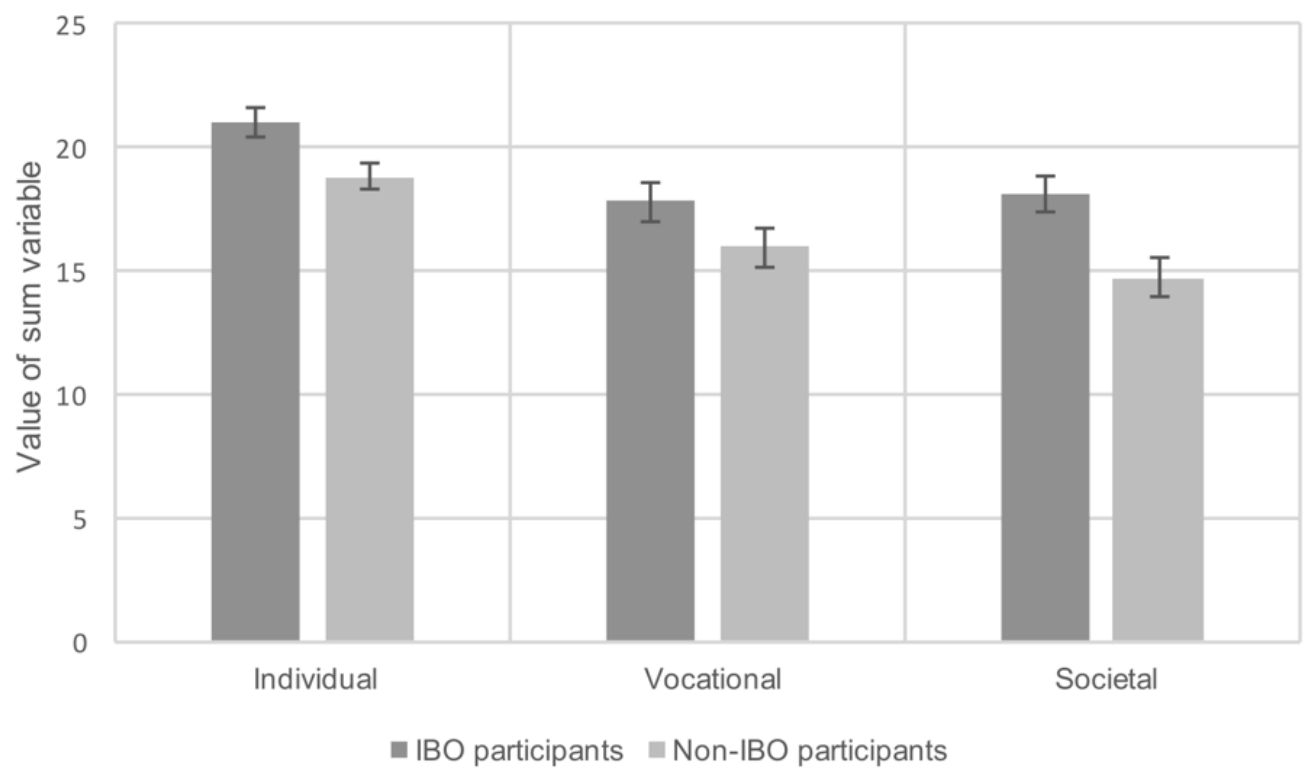

Figure 2. The mean sum scores of the dimensions of relevance in Finnish Biology Olympiad training, according to participants (years 2008-2014, N=35, error bars = SEM). The figure shows the differences between students who were selected for the International Biology Olympiad (IBO) and students who didn't qualify.

The students participating in refined Finnish IBO training $(\mathrm{N}=28)$ gave various reasons to be interested in biology. The most common themes were 'understanding the nature' and 'future studies or vocation', which almost half of the students mentioned in their open-ended answers. In total, the students mentioned themes belonging to the individual relevance dimension the most, but also societal and vocational relevance dimensions were prevalent (Table 6). 
Table 6. Students' reasons to be interested in biology $(N=28)$.

\begin{tabular}{|c|c|c|c|}
\hline \multirow[t]{2}{*}{$\begin{array}{l}\text { Dimension of } \\
\text { relevance }\end{array}$} & \multirow[t]{2}{*}{ Theme } & \multicolumn{2}{|c|}{$\begin{array}{l}\text { The amount of students }(\mathrm{N}=28) \\
\text { mentioning the theme }\end{array}$} \\
\hline & & Rater 1 & Rater 2 \\
\hline \multirow[t]{5}{*}{ Individual relevance } & Understanding the nature & 11 & \\
\hline & Practical applications of biology & 7 & 9 \\
\hline & Consistency of biology & 3 & 3 \\
\hline & Understanding oneself & 1 & 1 \\
\hline & Hobbies and free time activities & 1 & 1 \\
\hline \multirow[t]{3}{*}{ Societal relevance } & $\begin{array}{l}\text { All-round education / general, layperson } \\
\text { knowledge }\end{array}$ & 5 & 8 \\
\hline & Caring about environment and nature & 4 & 4 \\
\hline & Topicality of biology & 2 & 3 \\
\hline $\begin{array}{l}\text { Vocational } \\
\text { relevance }\end{array}$ & Future studies / vocation & 11 & 11 \\
\hline
\end{tabular}

Cohen's kappa value for inter-rater agreement was 0.805 .

The students' aims and expectations for the refined training were mostly classified to belong to the individual dimension of relevance. The most common aims and expectations were 'learning practical skills' and 'deepening knowledge in a special topic of interest'. Only a few themes could be classified to represent vocational or societal relevance (Table 7 ). 
Table 7. Students' aims and expectations before the training week $(\mathrm{N}=28)$.

\begin{tabular}{llll}
\hline $\begin{array}{l}\text { Dimension of } \\
\text { relevance }\end{array}$ & Theme & $\begin{array}{l}\text { The amount of students } \\
\text { (N=28) mentioning the } \\
\text { theme } \\
\text { Rater 1 }\end{array}$ & Rater 2 \\
\hline & & 6 & 5 \\
\hline Individual relevance & Getting to know new people & 17 & 19 \\
& Learning practical skills & 3 & 3 \\
& Learning to apply knowledge & 3 & 9 \\
& Deepening knowledge in a special topic of & 11 & 4 \\
& interest & & 8 \\
& Performing well & 4 & 4 \\
& Research-related topics & 6 & 4 \\
& Getting to the IBO team & 4 & 3 \\
\hline & Getting new experiences & 3 & 7 \\
& Reviewing one's knowledge & 1 & 5 \\
\hline Vocational relevance & Matriculation exams & 7 & 3 \\
& Future studies & 1 & 1 \\
\hline Gocietal relevance & Getting to know companies / industry & 3 & 7 \\
\hline
\end{tabular}

Cohen's kappa value for inter-rater agreement was 0.803.

The prevalence the individual dimension of relevance was even clearer when analysing the students' learning experiences from the refined training. Almost all the students experienced that they had learned theoretical knowledge, and most students mentioned also practical skills. However, only a few students experienced that they had learned something belonging to the dimension of vocational or societal relevance (Table 8). 
Table 8. Students' learning experiences after the training week, based on the post-training questionnaire and the interview $(\mathrm{N}=28)$.

\begin{tabular}{llll}
\hline Dimension of relevance & Theme & \multicolumn{2}{l}{$\begin{array}{l}\text { The amount of students } \\
\mathbf{( N = 2 8 )} \text { mentioning the } \\
\text { theme }\end{array}$} \\
\cline { 2 - 4 } & & Rater 1 & Rater 2 \\
\hline Individual relevance & Learning theoretical knowledge & 26 & 24 \\
& Learning practical work & 19 & 18 \\
& Learning about research & 7 & 9 \\
\hline Vocational relevance & Getting help to succeed at studies & 2 & 4 \\
& Science as a vocation & 2 & 2 \\
\hline Societal relevance & Science and society & 2 & 3 \\
\hline
\end{tabular}

Cohen's kappa value for inter-rater agreement was 0.820.

\section{Discussion}

This study answered to the two research questions through the quantitative and the qualitative parts of the study:

\subsection{The relevance of Biology Olympiad training for the participants}

In the quantitative part of this study, the aim was to examine the theoretical framework of relevant science education (Stuckey et al., 2013) used also in the qualitative part of this study. To measure the dimensions of relevance by Stuckey et al. (2013), an instrument was developed and tested to operationalize and measure relevance, but it should be refined and tested in further studies. Based on the results, the theoretical framework of relevance of science education (Stuckey et al., 2013) might be useful for qualitative analysis in these kinds of contexts. It was discovered that the three dimensions of relevance (individual, vocational and societal) are tightly connected: the students who considered the training to be relevant for them individually are more likely to experience it to be relevant also vocationally and societally.

Based on the results from the quantitative analysis, the difference between genders in any of the dimensions of relevance was not statistically significant. In many studies, gender has been observed to be an important factor predicting the achievement in biology (Britner, 2008), interest and motivation (Gedrovics, Wäreborn, \& J eronen, 2006; Prokop, Prokop, \& Tunnicliffe, 2007; Uitto, J uuti, Lavonen, \&Meisalo, 2006), self-efficacy beliefs (Zeldin, Britner, \& Pajares, 2008), observed relevance of biology 
(Schreiner \& Sjøberg, 2004) and choosing biological career (Lavonen et al., 2008; Uitto, 2014). However, the effect of gender may be different among students with high abilities. It would be important to research the effect of gender on high ability students to get more knowledge about this issue.

It is important to consider that only some of the students participating in the training were selected for the IBO. Participating in the IBO was a significant factor predicting the experienced individual, vocational and societal relevance of the training. The reason might be that 1) the students that experience the training to be more relevant for them will be more likely to be selected for the IBO team, 2) the students not qualifying for the IBO team develop negative views on the training, or 3) the students selected for the IBO team were unable to distinguish the effect of the training and the competition from each other, and actually the IBO competition itself affected their views.

To get more knowledge about the relevance of the training, students were also asked why biology (as a school subject) is relevant for them. The students considered that biology is a relevant subject to study and learn in itself, and in their reasoning, they expressed individual, vocational and societal dimensions of relevance. This is in accordance with the theoretical framework of relevance by Stuckey et al. (2013), and implicates that it is important to include all the three dimensions in relevant biology education, both in formal and out-of-school (non-formal) contexts.

\subsection{Possibilities to make Biology Olympiad training relevant for the participants}

To make science competitions more relevant for the participants, it is important to research their aims and expectations. According to the students, studying biology is relevant individually, vocationally and societally. However, students' aims and expectations did not evenly contain all the dimensions of relevance. In fact, most of the students expected the training to be only individually relevant for them, which may result from students' preconceptions about science competitions and training. Scientific competitions (e.g. IBO Coordinating Centre, 2015) are planned to be relevant in many ways, and it's useful to explain to the students what are the aims of the competition and training. According to Campbell et al. (2000), science competitions are expected to promote motivation and lead the students to contribute to society. Therefore, science competitions should not only promote interest in 
science, as relevant science education should also anticipate the future needs of the students (Stuckey et al., 2013), including vocational and societal aspects.

Students' views on the relevance of the training was also examined by asking what they had learned during the training. Students' learning experiences represented almost entirely the individual dimension of relevance, which is in accordance with their aims and expectations. However, it should be taken into account that when asking about learning experiences, the students tend to give concrete answers, which were classified to represent the individual dimension of relevance. In addition, the students may be unaware of their learning as learning may be informal: it is invisible, the learned knowledge is tacit and difficult to explain in detail (Eraut, 2004). However, assessing the relevance of non-formal science education might not be possible by analysing learning experiences, but those educational activities should be evaluated in their entirety (Tolppanen et al., 2015).

Moreover, students' aims and expectations are mostly related to the present or near future (e.g. 'getting to the IBO team', 'matriculation exams' or 'getting a course for the studies'). Notably, students' aims and expectations for out-of-school Olympiad training are primarily short-term, which might also explain the lack of vocational and societal components of relevance in this part. In addition, students' learning experiences reflect the same phenomenon: most of the learning is related to the individual dimension of relevance.

The vocational and societal dimensions of non-formal education may easily be neglected, unless this issue is addressed when developing such activities. In addition, if participants' aims and expectations only direct the development of Olympiad training, activities may only be individually relevant. All participants are not specifically aiming to study the specific discipline of the training, which is another reason to take vocational and societal relevance into account. In addition, we found out that biology is a relevant school subject for the participants of the trainings, individually, societally and vocationally. Hence, the science Olympiad training should be developed by taking these viewpoints into consideration as well.

This is a preliminary study to shed light on complex issues about developing nonformal education for young students. That's why it is needed to conduct similar studies in other contexts, such as in different countries and science disciplines to make further recommendations about developing non-formal science education and the Olympiad trainings for students with high abilities. 
The National Biology Competition and IBO training in Finland has been funded by the National Board of Education, organized in co-operation with the Association of Biology and Geography Teachers in Finland (BMOL), and supported by Aalto University, the University of Helsinki and the LUMA Centre Finland. We would also like to acknowledge university lecturer Viivi Virtanen for providing valuable comments for this study and doctoral student Anttoni Kervinen for helping in the investigator triangulation.

\section{References}

Abernathy, T. V., \& Vineyard, R. N. (2001). Academic competitions in science: What are the rewards for students? The Clearing House, 74(5), 269-276

Aikenhead, G. S. (2006). Science education for everyday life: Evidence-based practice. NewYork, NY: Teachers College Press.

Antink-Meyer, A., Bartos, S., Lederman, J . S., \&Lederman, N. G. (2016). Using Science Camps to Develop Understandings About Scientific Inquiry-Taiwanese Students in a Us Summer Science Camp. International J ournal of Science and Mathematics Education, 14(1), S29S53. doi: 10.1007/ s10763-014-9576-3

Britner, S. L. (2008). Motivation in High School Science Students: A Comparison of Gender Differences in Life, Physical, and Earth Science Classes. J ournal of Research in Science Teaching, 45(8), 955-970. doi: 10.1002/ tea.20249

Campbell, J . R., Wagner, H., \&Walberg, H. J . (2000). Academic competitions and programs designed to challenge the exceptionally talented. In K. A. Heller, F. J . Mönks, R. Subotnik \& R. J. Sternberg (Eds.), International handbook of giftedness and talent (pp. 523-536). Oxford, England: Pergamon.

Cleaves, A. (2005). The formation of science choices in secondary school. International J ournal of Science Education, 27(4), 471-486. doi: 10.1080/0950069042000323746

Cohen, J . (1960). A coefficient of agreement for nominal scales. Educational and Psychological Measurement, 20, 37- 46

Cohen, L., Manion, L., \& Morrison, K. (2013). Research methods in education. New York: Routledge.

Dillon, J . (2009). On Scientific Literacy and Curriculum Reform. International J ournal of Environmental and Science Education, 4(3), 201-213

Elo, S., \& Kyngas, H. (2008). The qualitative content analysis process. J Adv Nurs, 62(1), 107-115. doi: 10.1111/j.1365-2648.2007.04569.x

Eraut, M. (2004). Informal learning in the workplace. Studies in continuing education, 26(2), 247273

Eshach, H. (2007). Bridging in-school and out-of-school learning: Formal, non-formal, and informal education. J ournal of science education and technology, 16(2), 171-190

European Union. (2015). Science Education for Responsible Citizenship. Report to the European Commission of the expert group on science education. Retrieved from http:// ec.europa.eu/research/swafs/ pdf/ pub_science_education/KI-NA-26-893-EN-N.pdf doi: $10.2777 / 12626$ 
Gedrovics, J., Wäreborn, I., \&J eronen, E. (2006). Science subjects choice as a criterion of students' attitudes to science. J ournal of Baltic Science Education, 1(9), 74-85

Hofstein, A., Eilks, I., \& Bybee, R. (2011). Societal Issues and Their Importance for Contemporary Science Education-a Pedagogical J ustification and the State-of-the-Art in Israel, Germany, and the USA. International J ournal of Science and Mathematics Education, 9(6), 14591483. doi: 10.1007/s10763-010-9273-9

Hofstein, A., \& Kesner, M. (2006). Industrial chemistry and school chemistry: Making chemistry studies more relevant. International J ournal of Science Education, 28(9), 1017-1039. doi: 10.1080/09500690600702504

Holbrook, J . (2008). Introduction to the special issue of science education international devoted to PARSEL. Science Education International, 19(3), 257-266

IBO Coordinating Centre. (2015). A Guide to the International Biology Olympiad. Retrieved from http:/ / www.ibo-info.org/ pdf/ IBO-Guide.pdf

Krapp, A., \&Prenzel, M. (2011). Research on Interest in Science: Theories, methods, and findings. International J ournal of Science Education, 33(1), 27-50. doi: 10.1080/09500693.2011.518645

Lavonen, J ., Gedrovics, J ., Byman, R., Meisalo, V., J uuti, K., \& Uitto, A. (2008). Students' Motivational Orientations and Career Choice in Science and Technology: A Comparative Investigation in Finland and Latvia. J ournal of Baltic Science Education, 7(2), 86-102

Levitt, K. E. (2001). An analysis of elementary teachers' beliefs regarding the teaching and learning of science. Science education, 86(1), 1-22

Lim, S. S., Cheah, H.-M., \&Hor, T. A. (2014). Science Olympiads as Vehicles for Identifying Talent in the Sciences: The Singapore Experience Communicating Science to the Public (pp. 195211): Springer.

Newton, D. P. (1988). Relevance and science education. Educational Philosophy and Theory, 20(2), 7-12

Oliver, M., \&Venville, G. (2011). An Exploratory Case Study of Olympiad Students' Attitudes towards and Passion for Science. International J ournal of Science Education, 33(16), 22952322. doi: 10.1080/09500693.2010.550654

Osborne, J ., Simon, S., \& Collins, S. (2003). Attitudes towards science: a review of the literature and its implications. International J ournal of Science Education, 25(9), 1049-1079. doi: 10.1080/0950069032000032199

Prokop, P., Prokop, M., \&Tunnicliffe, S. D. (2007). Is biology boring? Student attitudes toward biology. J ournal of biological education, 42(1), 36-39

Roberts, D. A. (2007). Scientific literacy / science literacy. In S. K. Abell \&N. G. Lederman (Eds.), Handbook of research on science education (pp. 729-780). Mahwah, NJ : Lawrence Erlbaum Associates.

Roberts, D. A., \& Bybee, R. W. (2014). Scientific literacy, science literacy, and science education. In N. G. Lederman \& S. K. Abell (Eds.), Handbook of Research on Science Education (Vol. II, pp. 545-558). New York, NY: Routledge.

Sahin, A., Gulacar, O., \& Stuessy, C. (2015). High School Students' Perceptions of the Effects of International Science Olympiad on Their STEM Career Aspirations and Twenty-First Century Skill Development. Research in Science Education, 45(6), 785-805. doi: 10.1007/s11165-014-9439-5

Schreiner, C., \& Sjøberg, S. (2004). Sowing the seeds of ROSE. Background, Rationale, Questionnaire Development and Data Collection for ROSE (The Relevance of Science Education) - a comparative study of students' views of science and science education (Acta Didactica 4/2004). Oslo: Dept. of Teacher Education and School Development, University of Oslo. 
Simon, S., \&Amos, R. (2011). Decision making and use of evidence in a socio-scientific problem on air quality. In T. D. Sadler (Ed.), Socio-scientific issues in the classroom. Contemporary Trends and Issues in Science Education. (pp. 167-192). Dordrecht: Springer.

Sjøberg, S., \& Schreiner, C. (2010). The ROSE project: An overview and key findings. Oslo: University of Oslo, 1-31

Staziński, W. (1988). Biological competitions and Biological Olympiads as a means of developing students' interest in biology. International J ournal of Science Education, 10(2), 171-177

Stuckey, M., Hofstein, A., Mamlok-Naaman, R., \& Eilks, I. (2013). The meaning of 'relevance' in science education and its implications for the science curriculum. Studies in Science Education, 49(1), 1-34. doi: 10.1080/03057267.2013.802463

Tirri, K. (2000). Finland Olympiad Studies: What Factors Contribute to the Development of Academic Talent in Finland?

Tirri, K., \&Nokelainen, P. (2010). The influence of self-perception of abilities and attribution styles on academic choices: Implications for gifted education. Roeper Review, 33(1), 26-32

Tolppanen, S., Vartiainen, J ., Ikävalko, V.-M., \&Aksela, M. (2015). Relevance of non-formal education in science education Relevant Chemistry Education (pp. 335-354): Springer.

Uitto, A. (2014). Interest, Attitudes and Self-Efficacy Beliefs Explaining Upper-Secondary School Students' Orientation Towards Biology-Related Careers. International J ournal of Science and Mathematics Education, 12(6), 1425-1444. doi: 10.1007/ s10763-014-9516-2

Uitto, A., J uuti, K., Lavonen, J ., \& Meisalo, V. (2006). Students' interest in biology and their outof-school experiences. J ournal of Biological Education, 40(3), 124-129. doi: Doi 10.1080/00219266.2006.9656029

Urhahne, D., Ho, L. H., Parchmann, I., \&Nick, S. (2012). Attempting to predict success in the qualifying round of the International Chemistry Olympiad. High Ability Studies, 23(2), $167-$ 182. doi: 10.1080/13598139.2012.738324

Vesterinen, V.-M., Tolppanen, S., \&Aksela, M. (2016). Toward citizenship science education: what students do to make the world a better place? International J ournal of Science Education, 38(1), 30-50. doi: 10.1080/09500693.2015.1125035

Vihma, L., \&Aksela, M. (2014). Inspiration, J oy, and Support of STEM for Children, Youth and Teachers through the Innovative LUMA Collaboration Finnish Innovations and Technologies in Schools (pp. 129-144): Springer.

Zeldin, A. L., Britner, S. L., \&Pajares, F. (2008). A comparative study of the self-efficacy beliefs of successful men and women in mathematics, science, and technology careers. J ournal of Research in Science Teaching, 45(9), 1036-1058 